\title{
Influence of Graphene Oxide Concentration when Fabricating an Electrochemical Biosensor for DNA Detection
}

\author{
Elena A. Chiticaru ${ }^{1}$, Luisa Pilan ${ }^{2, *}\left(\mathbb{0}\right.$, Celina-Maria Damian ${ }^{3}$, Eugeniu Vasile ${ }^{4}$, Jorge S. Burns ${ }^{1,5}$ \\ and Mariana Ioniţă ${ }^{1,3, *}$ \\ 1 Faculty of Medical Engineering, University Politehnica of Bucharest, Gh Polizu 1-7, \\ 011061 Bucharest, Romania \\ 2 Department of Inorganic Chemistry, Physical Chemistry and Electrochemistry, University Politehnica of \\ Bucharest, 1-7, Polizu St., 011061 Bucharest, Romania \\ 3 Advanced Polymer Materials Group, University Politehnica of Bucharest, Gh Polizu 1-7, \\ 011061 Bucharest, Romania \\ 4 Faculty of Applied Chemistry and Material Science, University Politehnica of Bucharest, 1-7 Gh. Polizu, \\ 011061 Bucharest, Romania \\ 5 Laboratory of Cellular Therapies, Department of Medical and Surgical Sciences for Children \& Adults, \\ University Hospital of Modena and Reggio Emilia, 41121 Modena, Italy \\ * Correspondence: luisa_pilan@yahoo.com (L.P.); mariana.ionita@polimi.it (M.I.)
}

Received: 26 July 2019; Accepted: 20 September 2019; Published: 26 September 2019

\begin{abstract}
We have investigated the influence exerted by the concentration of graphene oxide (GO) dispersion as a modifier for screen printed carbon electrodes (SPCEs) on the fabrication of an electrochemical biosensor to detect DNA hybridization. A new pretreatment protocol for SPCEs, involving two successive steps in order to achieve a reproducible deposition of $\mathrm{GO}$, is also proposed. Aqueous GO dispersions of different concentrations $(0.05,0.1,0.15$, and $0.2 \mathrm{mg} / \mathrm{mL}$ ) were first drop-cast on the SPCE substrates and then electrochemically reduced. The electrochemical properties of the modified electrodes were investigated after each modification step by cyclic voltammetry (CV) and electrochemical impedance spectroscopy (EIS), while physicochemical characterization was performed by scanning electron microscopy (SEM), X-ray photoelectron spectroscopy (XPS), and Raman spectroscopy. Finally, the sensing platform was obtained by the simple adsorption of the single-stranded DNA probe onto the electrochemically reduced GO (RGO)-modified SPCEs under optimized conditions. The hybridization was achieved by incubating the functionalized SPCEs with complementary DNA target and detected by measuring the change in the electrochemical response of $\left[\mathrm{Fe}(\mathrm{CN})_{6}\right]^{3-/ 4-}$ redox reporter in $\mathrm{CV}$ and EIS measurements induced by the release of the newly formed double-stranded DNA from the electrode surface. Our results showed that a higher GO concentration generated a more sensitive response towards DNA detection.
\end{abstract}

Keywords: reduced graphene oxide; electrochemical biosensor; screen printed carbon electrodes; DNA adsorption

\section{Introduction}

Increased prevalence of genetic analysis fosters development of biosensors for rapid and cost-effective detection of specific DNA sequences within a broadening range of human diseases. Several approaches for DNA analysis systems such as optical (fluorescent, surface plasmon resonance luminescent, colorimetric, etc.) [1-5], piezoelectric [6], or electrochemical [7-9] have been proposed. The electrochemical approach is promising because it can provide the above advantages 
whilst also offering the possibility of self-powered miniaturized devices relevant for point-of-care applications [10-12].

An impedimetric DNA biosensor converts the biochemical affinity binding event of the target molecule with the DNA probe into an analytical signal corresponding to the charge-transfer resistance $\left(\mathrm{R}_{\mathrm{ct}}\right)$ between a redox-active species from the solution and the electrode surface. In contrast to classic approaches for DNA sensors, with target DNA labeled by an enzyme or a fluorophore, electrochemical impedance spectroscopy (EIS) offers label-free detection in addition to the advantages of relative simplicity, low cost, ease of miniaturization, and portability $[13,14]$. Other electrochemical detection methods include the common amperometric or voltammetric techniques, such as cyclic voltammetry $(\mathrm{CV})$, differential pulse voltammetry and square-wave voltammetry, which involve the measurement of a current related to the analyte concentration under controlled potential conditions $[15,16]$. EIS is a technique of choice because it can detect significant changes in the signal in a low target concentration range $[14,17]$ and is non-destructive, due to the low amplitude voltage perturbation that is much smaller than that used in amperometric testing [18-21].

Graphene has been studied for electrochemical sensing because of its outstanding properties, e.g., very high electrical conductivity, chemical stability, large surface-to-volume ratio, and excellent carrier mobility. However, this two-dimensional (2D) material is also highly hydrophobic, making it difficult for it to interact with biological molecules such as nucleic acids [22,23]. Graphene oxide (GO) and reduced graphene oxide (RGO) represent alternatives with oxygenated functionalities introduced into the carbon structure that enable dispersibility in water [24,25]. However oxygenated functionalities disrupt structural uniformity and compromise conductivity, so synthesis of RGO by various methods, e.g., thermal, chemical, or electrochemical approaches has aimed to achieve a balance between the highly conductive properties of pristine graphene and the functionalities of GO, retaining a sufficient number of electroactive sites on the surface to improve biosensor sensitivity [26-28]. DNA can be immobilized on graphenic surfaces by both covalent and non-covalent (physical adsorption) approaches. The main mechanism of DNA adsorption on RGO consists of the noncovalent $\pi-\pi$ stacking between the aromatic rings of DNA nucleobases with hexagonal carbon rings forming the graphenic lattice, followed by hydrogen bonding and electrostatic repulsion between the oxygenated functional groups and oligonucleotides [29-31]. The adsorption of single-stranded (ss) DNA on graphene is reported to be efficient even in low ionic strength buffers, whereas double-stranded (ds) DNA, with its double-helical structure consisting of a negatively charged phosphate backbone surrounding the positively charged nucleobases, has a slower rate of adsorption [32-35]. This weaker interaction between RGO and dsDNA results in a quick desorption after hybridization of ssDNA probe with its complementary ssDNA target. Therefore, the high differentiation capacity of RGO between these configurations of DNA biomolecules has been frequently exploited in the design of electrochemical DNA biosensors [36-40].

Recently, screen-printed electrodes (SPEs) have been adopted for electroanalysis [41], favored over the traditional carbon electrodes (glassy carbon and carbon paste), because they are portable, compact, and inexpensive to manufacture, facilitating mass production of biosensors of high quality and reproducibility, suitable for point-of-care applications [42]. Even if SPEs and graphene have been extensively investigated, the large-scale production of such electrochemical detection platforms is rarely reported. The performance of an electrochemical biosensor for oligonucleotide hybridization can be strongly influenced by fabrication aspects.

In the latest years, several pretreatment procedures for the SPCE surface aiming to improve the sensitivity and reproducibility of the results have been reported [43-50]. Improvement of the electrochemical performance of screen-printed carbon electrodes by UV/ozone modification was very recently described [43]. The augmented electron transfer rate and the decreased peak-to-peak potential separation from $170 \mathrm{mV}$ to $112 \mathrm{mV}$ were mainly attributed to an increase in oxygen functional groups [43]. Nonetheless, due to its simplicity, the electrochemical pretreatment is often used for improving carbon electrode responses. This improvement was explained by a substantial removal of the organic binder, inducing a clear exposure of the micrometer-sized graphite particles at the electrode 
surface [49]. Several approaches for improving the voltammetric behavior of SPCEs, presented as activation or electrochemical cleaning procedures, consisted in repetitive cyclic voltammograms in various media: in diluted $\mathrm{H}_{2} \mathrm{O}_{2}$ from +1.0 to $-0.7 \mathrm{~V} \mathrm{[46],} \mathrm{in} 0.5 \mathrm{M} \mathrm{H}_{2} \mathrm{SO}_{4}$ from $-1 \mathrm{~V}$ to $+1 \mathrm{~V}$ [48], in phosphate buffer solutions from -0.6 to $+1.6 \mathrm{~V}$ [49], or only by applying anodic potentials ranging from $+0.2 \mathrm{~V}$ to $+2 \mathrm{~V}$ [47]. However, for all these electrochemical procedures, no reproducibility studies have been reported and the improvement in the response was presented either as a reduction of the semicircle in the Nyquist plot at the pre-treated SPCE [49] or as a narrower peak-to-peak separation (no $\triangle \mathrm{Ep}$ values) of the recorded voltammograms [46] for the reporter redox probes.

Among various transfer methods engineered for transfer of graphenic materials to enhance electrode performance, wet chemical methods have gained popularity by being relatively simple, convenient and scalable [51,52]. The most frequently encountered technique of employing SPEs for graphene investigation in electrochemistry requires modification of a graphite-based or carbon black-based electrode by drop-casting graphene or one of its derivatives on the SPE's surface [53]. However, the technique can lead to the modified electrode having poor sensitivity and reproducibility, especially if all the modification steps are not carefully controlled and standardized.

Another reported method to design graphene-based SPEs is the direct electrochemical reduction of the dispersed graphene oxide at the substrate electrode $[54,55]$. Although such electrochemical approaches can provide a more accurate control of the film thickness, they are poorly applicable to a large-scale production [16]. Inkjet-printing has been reported by Tuantranont et al. as a large-scale modifying approach for SPEs [56] that allows controllable dispersion deposition $[57,58]$. By modulating the number of printed layers, SPCEs modified with a graphene-poly(3,4-ethylenedioxythiophene): poly(styrenesulfonate) dispersion conducted to a satisfactory reproducibility for various analytes. However, the rheological properties of the inks frequently represent a major limitation of this strategy [16].

We here report a new, simplified, reproducible, and potentially scalable protocol for fabricating RGO-modified SPCEs (RGO-SPCEs). A preliminary two-step electrochemical treatment of commercially available SPCEs had a crucial effect on the electrochemical behavior of SPCEs and the reproducibility of the electrochemical signal. After pretreatment, the electrochemical properties such as peak-to-peak separation $(\triangle \mathrm{Ep})$ and electron transfer resistance (Rct) of the ferri/ferrocyanide redox reporter in the solution were significantly improved. Moreover, the performance of these electrodes as a DNA hybridization detection platform could be simply modulated by varying the concentration of dispersed GO used for SPCE modification.

\section{Materials and Methods}

\subsection{Reagents and Instrumentation}

Graphene oxide (GO) in $\mathrm{H}_{2} \mathrm{O}(2 \mathrm{mg} / \mathrm{mL}), \mathrm{HCl}, \mathrm{KCl}, \mathrm{HNa}_{2} \mathrm{O}_{4} \mathrm{P}$, and $\mathrm{H}_{2} \mathrm{NaO}_{4} \mathrm{P}$ were procured from Sigma-Aldrich (St. Louis, MO, USA), while $\mathrm{K}_{3}\left[\mathrm{Fe}(\mathrm{CN})_{6}\right]$ and $\mathrm{K}_{4}\left[\mathrm{Fe}(\mathrm{CN})_{6}\right] \times 3 \mathrm{H}_{2} \mathrm{O}$ were acquired from Merck Co., (Darmstadt, Germany). Single-stranded DNA probe (5'-TTT CAA CAT CAG TCT GAT AAG CTA TCT CCC-3'), its complementary single-stranded DNA target (5'-GGG AGA TAG CTT ATC AGA CTG ATG TTG AAA-3'), and IDTE buffer were obtained from Integrated DNA Technologies, Inc (Coralville, IA, USA). Before and after any modification, the electrodes were washed with ultrapure water (Adrona Crystal EX water purification system, $18.2 \mathrm{M} \Omega \times \mathrm{cm}$ resistivity).

Electrochemical measurements were performed at room temperature $\left(\sim 25{ }^{\circ} \mathrm{C}\right)$ with a potentiostat/galvanostat Autolab PGSTAT 204 (Metrohm Autolab, the Netherlands) controlled by NOVA 2.1 software. The experiments were carried out using a three-electrode system consisting of a screen-printed carbon electrode (SPCE-DRP 110 from DropSens, Spain) with $4 \mathrm{~mm}$ internal diameter as a working electrode $(\mathrm{WE})$, a platinum wire auxiliary electrode, and a $\mathrm{Ag} / \mathrm{AgCl}(3 \mathrm{M} \mathrm{KCl})$ reference electrode in order to reference all potentials. The electrochemical cell containing all three electrodes was placed in a Faraday cage (Metrohm Autolab, the Netherlands) to shield the electrochemical system 
against electromagnetic interference. Electrochemical characterization of functionalized electrodes was done by cyclic voltammetry (CV) and electrochemical impedance spectroscopy (EIS). EIS measurements were carried out in the frequency range of $0.01 \mathrm{~Hz}$ to $100 \mathrm{kHz}$, at $10 \mathrm{mV}$ AC amplitude, and an applied bias DC potential of $+0.2 \mathrm{~V}$, while in $\mathrm{CV}$ a scan rate of $0.05 \mathrm{~V} / \mathrm{s}$ was applied. All electrochemical measurements were carried out in $1 \mathrm{mM} \mathrm{K}_{3}\left[\mathrm{Fe}(\mathrm{CN})_{6}\right] / \mathrm{K}_{4}\left[\mathrm{Fe}(\mathrm{CN})_{6}\right](1: 1)$ redox probe in $0.1 \mathrm{M} \mathrm{KCl}$ solution. The impedance spectra obtained were represented as Nyquist plots in a complex plane and fitted by a Randles equivalent circuit.

The morphology of the modified electrodes was investigated by scanning electron microscopy (SEM), while the structural characterization was done by X-ray photoelectron spectroscopy (XPS) and Raman spectroscopy. SEM images were obtained with an electronic scanning microscope (SEM-QUANTA INSPECT F) by recording the resultant secondary electron beam with $30 \mathrm{keV}$ energy. XPS analysis was performed on a K-Alpha spectrometer from Thermo Scientific (Waltham, MA, USA) equipped with a monochromated $\mathrm{Al} \mathrm{K} \alpha$ source $(1486.6 \mathrm{eV})$, operating in vacuum at a base pressure of $2 \times 10^{-9}$ mbar. Flood gun compensated charging effects, and binding energies were calibrated by placing the $\mathrm{C} 1$ s peak at $284.8 \mathrm{eV}$ as an internal reference. Raman measurements were performed with a Renishaw inVia Raman confocal spectrometer, using a $473 \mathrm{~nm}$ laser excitation (Renishaw, Brno-Černovic, Czech Republic), the 100× objective, and 5\% laser power.

\subsection{Preparation and Testing of the Modified Electrodes}

The pretreatment of SPCEs prior to GO modification consisted of five CV cycles from +0.5 to $-1.5 \mathrm{~V}$ in $0.1 \mathrm{M} \mathrm{HCl}$, followed by two CV cycles from 0 to $+2 \mathrm{~V}$ in phosphate buffer solution (0.1 M PBS, pH 7) at a scan rate of $0.05 \mathrm{~V} / \mathrm{s}$. The $\mathrm{CV}$ response of the $\mathrm{Fe}(\mathrm{CN})_{6}{ }^{3-/ 4-}$ redox species at the pristine unmodified SPCE was poor, with a large peak separation of $195 \pm 28 \mathrm{mV}$ ( $n=5$ devices), indicating a slow electron transfer rate and irreversible electrochemical process. However, after the electrochemical pretreatment the difference between the peak potentials ( $\triangle \mathrm{Ep}$ ) was reduced to $93 \pm 2 \mathrm{mV}$ for all SPCEs. After this activation treatment, the electrodes were washed in ultrapure water (UPW), dried, and coated with PBS by very carefully dropping $1 \mu \mathrm{L}$ solution on the whole surface of the working electrode without crossing the margin (this step proved to be very important in order to achieve a reproducible deposition of GO). After the solution dried on the carbon surface, the electrode was washed again with UPW then dried at $50{ }^{\circ} \mathrm{C}$ in the oven. Subsequently, $3 \mu \mathrm{L} \mathrm{GO}(0.05,0.1,0.15$, and $0.2 \mathrm{mg} / \mathrm{mL})$ was carefully dropped on the dry SPCE surface. After drying at room temperature for 2 hours, GO-modified SPCEs (GO-SPCEs) were electrochemically reduced by five CV cycles from 0 to $-1.5 \mathrm{~V}, 0.05 \mathrm{~V} / \mathrm{s}$, in $0.5 \mathrm{M} \mathrm{KCl}$, and then again dried at room temperature, and washed with UPW. In order to observe the electrode response after each stage of surface modification, $\mathrm{CVs}$ and impedimetric spectra were recorded in the presence of a $\mathrm{Fe}(\mathrm{CN})_{6}{ }^{3-/ 4-}$ redox system.

Finally, the ssDNA probe was immobilized by carefully dropping $6 \mu \mathrm{L}$ DNA solution $(10 \mu \mathrm{M})$ on the RGO-SPCEs. After drying at room temperature, the electrodes were washed with UPW in order to remove weakly adsorbed nucleotides at the RGO surface. Afterwards, the SPCEs were introduced in $30 \mu \mathrm{L}$ DNA target solution $\left(100 \mathrm{nM}\right.$ ) to allow the formation of the hybridized dsDNA (at $58^{\circ} \mathrm{C}$ for one hour). If not used immediately, the electrodes were stored in air at $4{ }^{\circ} \mathrm{C}$.

\section{Results and Discussion}

\subsection{Morphological Characterization}

Scanning electron microscopy was used to investigate the surface morphology of GO and to evaluate the homogeneity of the resultant GO-modified surface. Images were taken from three different spots on every electrode and the ones reflecting the most relevant characteristics were chosen. The pictures were taken at two different magnifications $20 \mathrm{kX}$ (Figure 1a,c,e,g,i) and $100 \mathrm{kX}$ (Figure $1 \mathrm{~b}, \mathrm{~d}, \mathrm{f}, \mathrm{h}, \mathrm{j}$ ) in order to assess both surface homogeneity and morphology, respectively. Figure $1 \mathrm{a}, \mathrm{b}$ shows the SEM images of the pretreated SPCE surface, while Figure 1c-j is characteristic of the 
GO-SPCE-modified electrodes with different GO dispersion concentrations. A clear resemblance of the images corresponding to $0.05 \mathrm{mg} / \mathrm{mL} \mathrm{GO}$ (Figure 1c,d) and $0.1 \mathrm{mg} / \mathrm{mL}$ GO (Figure 1e,f) was observed, in such cases the electrodes surface was predominantly covered with thin smooth sheets of graphene, and the carbon substrate could still be observed. Likewise, the images corresponding to $0.15 \mathrm{mg} / \mathrm{mL}$ GO (Figure 1g,h) and $0.2 \mathrm{mg} / \mathrm{mL} \mathrm{GO}$ (Figure 1i,j) shared similar graphene-like morphology, showing wrinkled sheets with folded margins and seldomly agglomerated GO flakes. Finally, it was important to notice a homogeneous coverage on all four electrodes and an increased thickness of GO layers with the increase of the dispersion concentration.
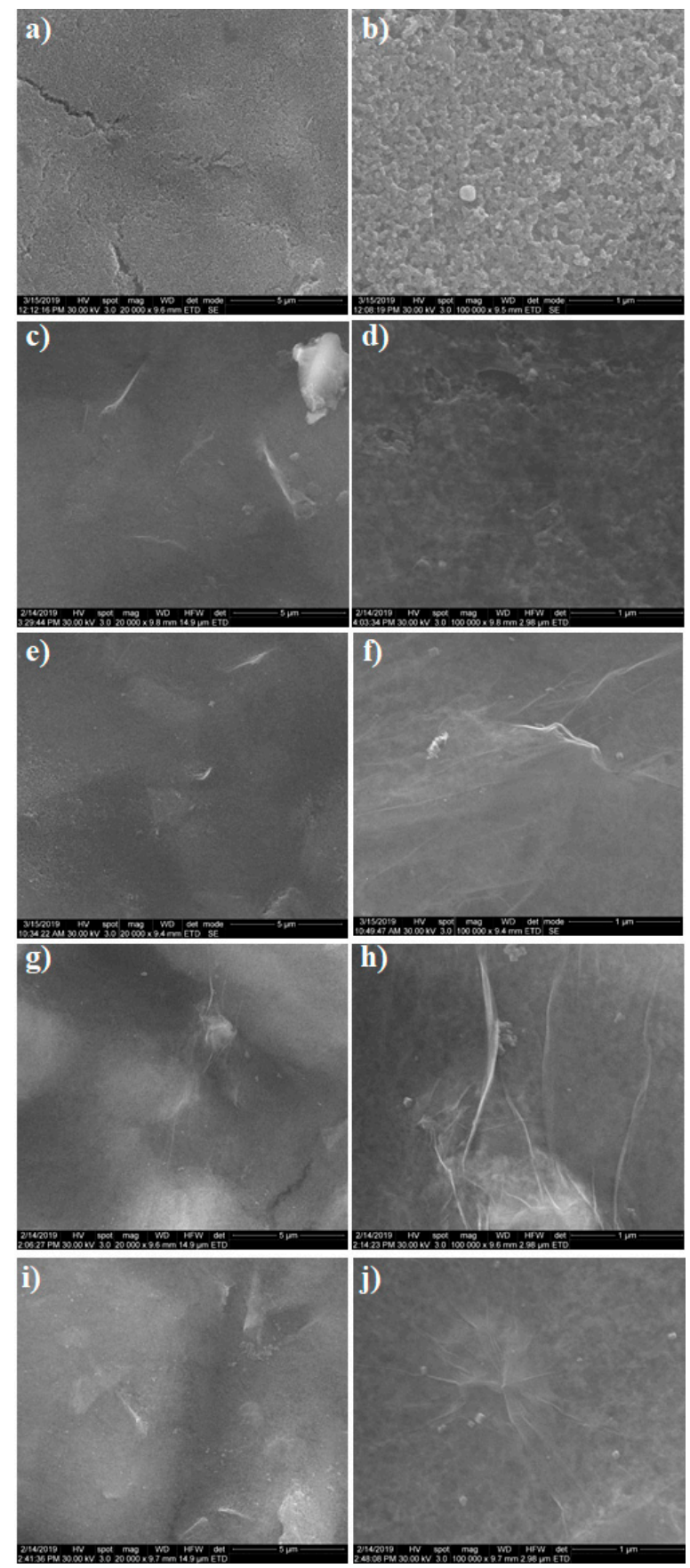

Figure 1. (a,b) SEM images of bare screen printed carbon electrode (SPCE). (c-j) SEM images of graphene oxide (GO) deposited on SPCE using different dispersion concentrations: (c,d) $0.05 \mathrm{mg} / \mathrm{mL}$; $(\mathbf{e}, \mathbf{f}) 0.1 \mathrm{mg} / \mathrm{mL} ;(\mathbf{g}, \mathbf{h}) 0.15 \mathrm{mg} / \mathrm{mL}$; and $(\mathbf{i}, \mathbf{j}) 0.2 \mathrm{mg} / \mathrm{mL}$. (a,c,e, $, \mathbf{g}, \mathbf{i})$ Images recorded at $20 \mathrm{kX}$ magnification. $(\mathbf{b}, \mathbf{d}, \mathbf{f}, \mathbf{h}, \mathbf{j})$ Images recorded at $100 \mathrm{kX}$ magnification. 
SEM images were also recorded after the electrochemical reduction of graphene oxide. Figure 2 shows the characteristics of $0.15 \mathrm{mg} / \mathrm{mL}$ RGO obtained at $20 \mathrm{kX}$ (Figure 2a) and $100 \mathrm{kX}$ (Figure 2b) magnifications. The reduced form of GO maintained a similar morphology, showing a good coverage of the electrode with thin and slightly wrinkled layers that had a tendency to agglomerate. Similar characteristics were obtained for the other three concentrations of RGO-modified electrodes.
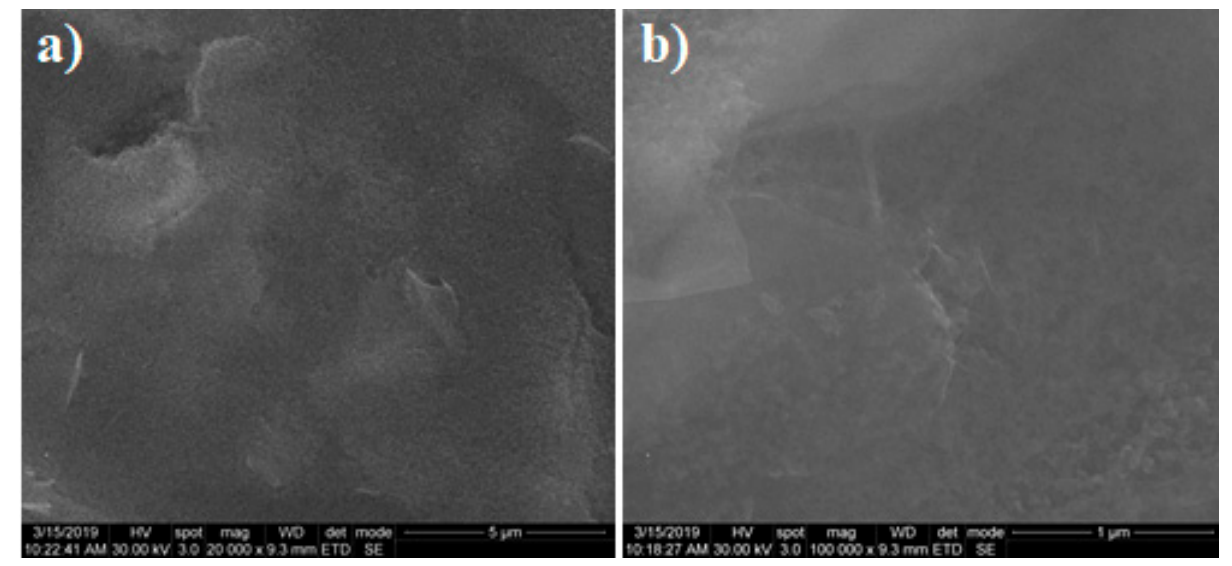

Figure 2. SEM images of reduced graphene oxide (RGO)-modified SPCE using $0.15 \mathrm{mg} / \mathrm{mL}$ dispersion recorded at (a) $20 \mathrm{kX}$ and (b) $100 \mathrm{kX}$ magnifications.

\subsection{Structural Characterization}

XPS provided an ultimate analysis of GO and RGO surface elemental composition. The survey spectra of all GO-based samples showed mainly the presence of carbon and oxygen with trace amount of nitrogen, which was attributed to process contamination. The reference used to evaluate the presence of oxygenated functional groups from the GO sheets was the $\mathrm{C}$ to $\mathrm{O}$ atomic ratio from XPS survey spectra. Based on this assessment it was observed that the GO samples had a very high oxygen atomic percentage ( $\mathrm{C} / \mathrm{O}$ ratio value close to 3 ). After electrochemical reduction there was a significant decrease in the signals for oxygen-containing functional groups, indicative of an efficient reduction of GO to RGO. Notably, the atomic ratio $\mathrm{C} / \mathrm{O}$ was increased to a value of almost 6 , indicating that the delocalized $\pi$ conjugation was to some extent restored in the RGO samples. This composition ratio was also calculated for a DNA sample, in order to assess its contribution to the decrease in C/O ratio after DNA immobilization. Thus, it was shown that a 1.67 value for $\mathrm{C} / \mathrm{O}$ ratio could slightly influence the overall atomic mapping of the RGO + DNA sensor by giving an increased C content.

Regarding the nitrogen and phosphorous, the sensors containing immobilized DNA showed increased P content reaching a maximum for the $0.15 \mathrm{mg} / \mathrm{mL}$ sample (Table 1).

A deeper analysis of the chemical state of $C$ element was acquired through the deconvolution of a high-resolution C1s XPS spectrum. The GO-based electrodes showed a sharp peak at $284.5 \mathrm{eV}$ that corresponded to carbon atoms involved in $\mathrm{C}-\mathrm{C}$ bonds, coming from the conjugated honey-comb lattice. The peaks observed at $285.1,286.7$, and $288.5 \mathrm{eV}$ could be assigned to $\mathrm{C}-\mathrm{H}$ species with $\mathrm{sp}^{3}$ hybridization, $\mathrm{C}-\mathrm{O}$, and $\mathrm{C}=\mathrm{O}$ bonding configurations, respectively, due to the oxidation and destruction of the $\mathrm{sp}^{2}$ atomic structure of graphite.

Comparing samples with different concentrations of GO (Figure 3), we observed a modification of the area corresponding to the $286.7 \mathrm{eV}$ band from $\mathrm{C} 1 \mathrm{~s}$ high-resolution spectra assigned to $\mathrm{C}-\mathrm{O}$ species. Generally, the peak area for $\mathrm{C}-\mathrm{O}$ decreased with the decrease of $\mathrm{GO}$ concentration; however, we observed a maximum of this peak area for the samples corresponding to $0.15 \mathrm{mg} / \mathrm{mL}$, slightly higher than the one corresponding to $0.2 \mathrm{mg} / \mathrm{mL}$. This trend can be assigned to the stacking of the GO layers after reaching a threshold limit value. 
Table 1. Carbon to oxygen ratio, nitrogen and phosphorous content of electrodes modified with four different concentrations of $\mathrm{GO}$, after electrochemical reduction and after immobilization of ssDNA probe on the surface (values for DNA probe: $\mathrm{C} / \mathrm{O}, 1.67 ; \mathrm{N}(\%), 10.02 ; \mathrm{P}(\%), 1.01)$.

\begin{tabular}{ccccc}
\hline Sample & & GO & RGO & RGO + DNA probe \\
\hline \multirow{3}{*}{$\mathbf{0 . 0 5} \mathbf{~ m g / m L}$} & $\mathbf{C} / \mathbf{O}$ & 3.599 & 5.588 & 6.551 \\
& $\mathbf{N}(\%)$ & 2.57 & 3.14 & 2.83 \\
& $\mathbf{P ( \% )}$ & 0 & 0 & 0.51 \\
\hline \multirow{3}{*}{$\mathbf{0 . 1} \mathbf{~} \mathbf{m} / \mathbf{m L}$} & $\mathbf{C} / \mathbf{O}$ & 2.983 & 5.646 & 6.692 \\
& $\mathbf{N}(\%)$ & 1.31 & 2.33 & 3.06 \\
& $\mathbf{P ( \% )}$ & 0 & 0 & 0.6 \\
\hline \multirow{3}{*}{$\mathbf{0 . 1 5} \mathbf{~ g / m L}$} & $\mathbf{C} / \mathbf{O}$ & 2.823 & 5.654 & 6.724 \\
& $\mathbf{N}(\%)$ & 2.06 & 2.17 & 3.13 \\
& $\mathbf{P ( \% )}$ & 0 & 0 & 1.04 \\
\hline \multirow{2}{*}{$\mathbf{0 . 2} \mathbf{~} \mathbf{m g} / \mathbf{m L}$} & $\mathbf{C} / \mathbf{O}$ & 2.739 & 5.88 & 7.23 \\
& $\mathbf{N}(\%)$ & 2.06 & 2.46 & 3.05 \\
& $\mathbf{P ( \% )}$ & 0 & 0 & 0.3 \\
\hline
\end{tabular}
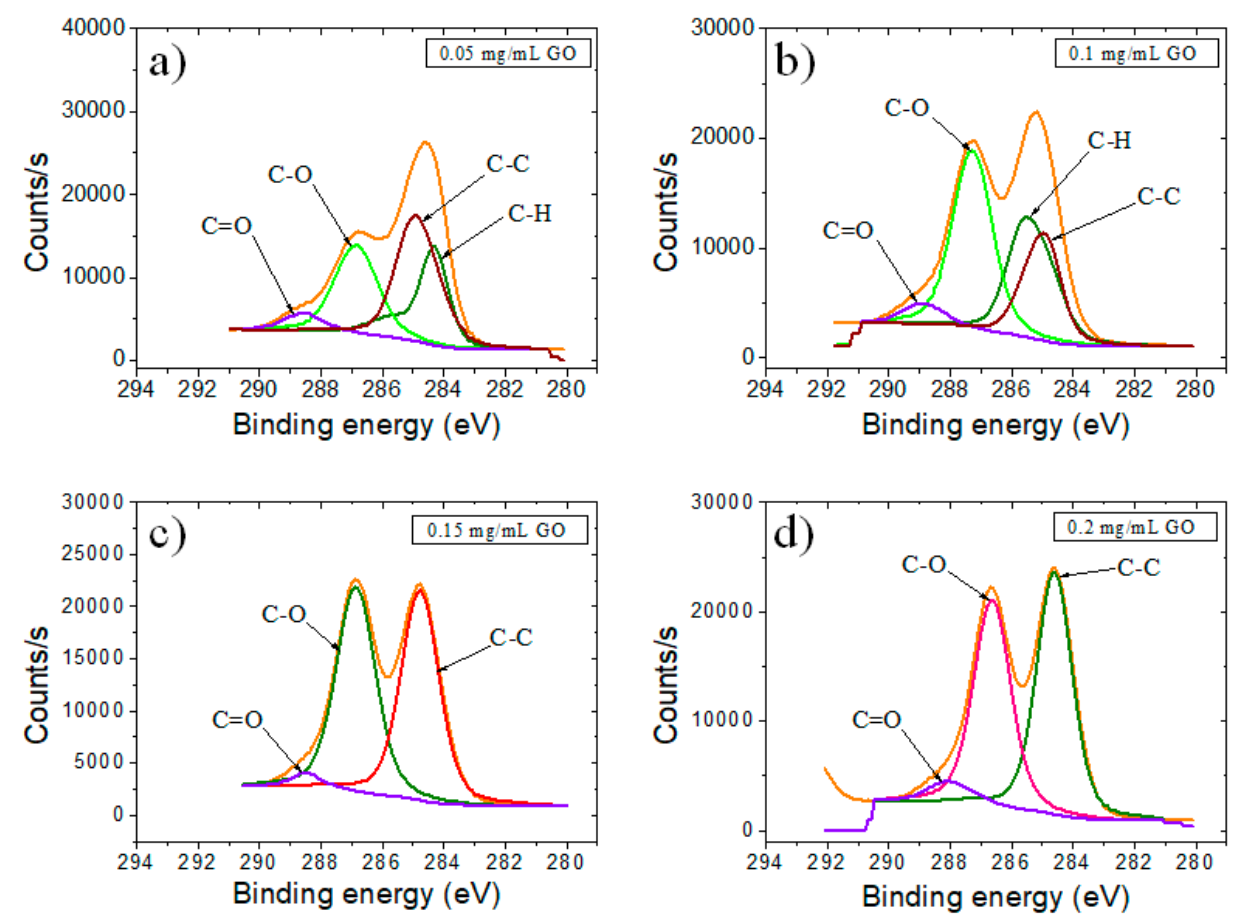

Figure 3. High-resolution C1 XPS spectra of SPCE modified with (a) $0.05 \mathrm{mg} / \mathrm{mL} \mathrm{GO;} \mathrm{(b)} 0.1 \mathrm{mg} / \mathrm{mL}$ GO; (c) $0.15 \mathrm{mg} / \mathrm{mL} \mathrm{GO}$; and (d) $0.2 \mathrm{mg} / \mathrm{mL} \mathrm{GO}$.

When GO was electrochemically reduced to RGO (Figure 4), it was observed a clear loss of oxygen moieties, that probably generated new $\mathrm{sp}^{2} \mathrm{C}-\mathrm{C}$ bonds. Accordingly, we observed an increased intensity of $\mathrm{C}-\mathrm{C}$ species. However, the remaining epoxy, hydroxyl and carboxylic groups translated through the presence of secondary peaks from 286 and $288 \mathrm{eV}$ would make aqueously dispersed RGO negatively charged, allowing a strong noncovalent binding between RGO and the nucleobases of ssDNA. 

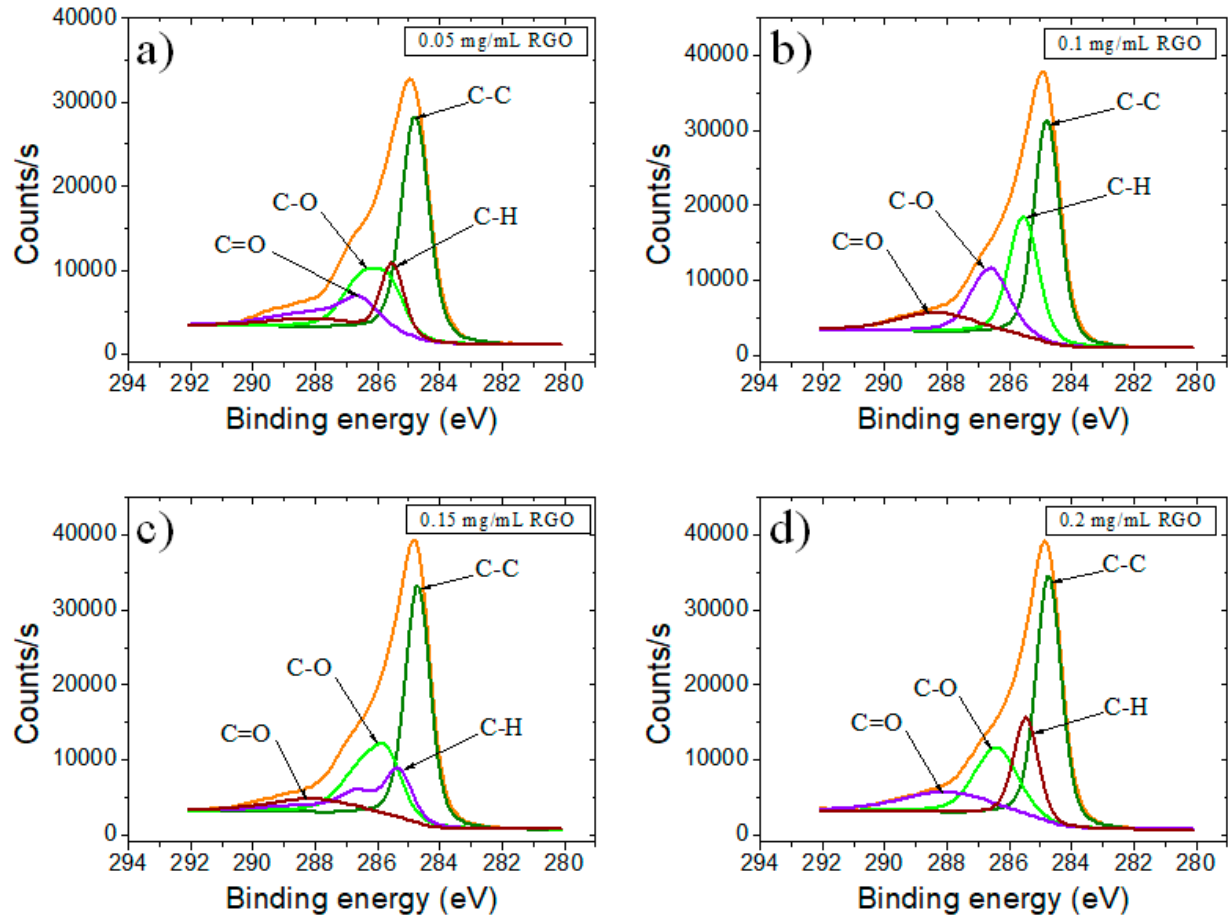

Figure 4. High-resolution C1 XPS spectra of SPCE modified with RGO using as precursor (a) $0.05 \mathrm{mg} / \mathrm{mL}$ GO; (b) $0.1 \mathrm{mg} / \mathrm{mL} \mathrm{GO;} \mathrm{(c)} 0.15 \mathrm{mg} / \mathrm{mL} \mathrm{GO;} \mathrm{and} \mathrm{(d)} 0.2 \mathrm{mg} / \mathrm{mL} \mathrm{GO}$.

When ssDNA was deposited on RGO (Figure 5), besides the presence of an increased $\mathrm{N}$ and $\mathrm{P}$ content in the wide range spectra, the clear shifting of the peak from $286.4 \mathrm{eV}$, that is related to the increase in the content of $\mathrm{C}-\mathrm{N}$ species from ssDNA, provided further evidence of the immobilization. Nonetheless, there was no notable difference between intensities of heteroatom secondary peaks $(\mathrm{C}-\mathrm{O}$, $\mathrm{C}-\mathrm{N}$, and $\mathrm{C}=\mathrm{O}$ respectively).
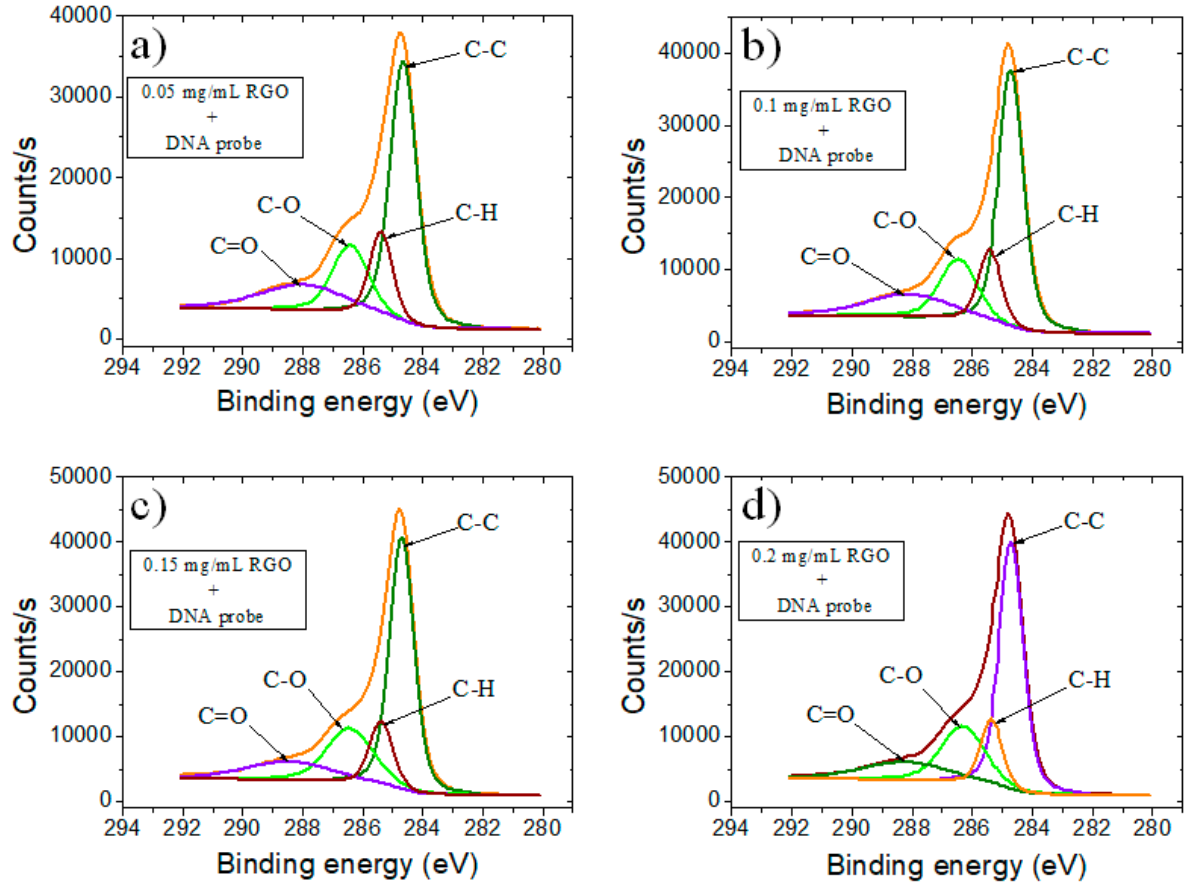

Figure 5. High-resolution C1 XPS spectra of $10 \mu \mathrm{m}$ DNA probe immobilized on the surface of SPCE modified with RGO using as precursor (a) $0.05 \mathrm{mg} / \mathrm{mL} \mathrm{GO;} \mathrm{(b)} 0.1 \mathrm{mg} / \mathrm{mL} \mathrm{GO;} \mathrm{(c)} 0.15 \mathrm{mg} / \mathrm{mL} \mathrm{GO;} \mathrm{and}$ (d) $0.2 \mathrm{mg} / \mathrm{mL} \mathrm{GO}$. 
From Table 2 it can be noticed that physical interactions between ssDNA and RGO layers determined a shift to higher binding energies for $\mathrm{C}-\mathrm{O}$ and $\mathrm{C}=\mathrm{O}$ secondary $\mathrm{C} 1 \mathrm{~s}$ peaks from 286.2 to $286.4 \mathrm{eV}$ and from 287.8 to $288.1 \mathrm{eV}$, respectively. Moreover, for each concentration the secondary $\mathrm{C} 1 \mathrm{~s}$ peaks were at the same position, meaning that in each case efficient interactions were formed.

Table 2. Binding energies of specific bonds existing in graphene oxide, reduced graphene oxide, DNA probe immobilized on RGO, and DNA probe on a plastic substrate (values for DNA probe: C-C, 284.7; $\mathrm{C}-\mathrm{O}, 286.2 ; \mathrm{C}=\mathrm{O}, 287.8$ ).

\begin{tabular}{|c|c|c|c|c|}
\hline Sample & & GO & RGO & RGO + DNA probe \\
\hline & $\mathrm{C}-\mathrm{C}$ & 285.4 & 284.8 & 284.7 \\
\hline \multirow[t]{4}{*}{$0.05 \mathrm{mg} / \mathrm{mL}$} & $\mathbf{C}-\mathbf{H}$ & 285.1 & 285.5 & 285.4 \\
\hline & $\mathrm{C}-\mathrm{O}$ & 286.8 & 286.6 & 286.4 \\
\hline & $\mathrm{C}=\mathrm{O}$ & 288.5 & 288.2 & 288.1 \\
\hline & $\mathrm{C}-\mathrm{C}$ & 284.8 & 284.8 & 284.7 \\
\hline \multirow[t]{4}{*}{$0.1 \mathrm{mg} / \mathrm{mL}$} & C-H & 285.4 & 285.5 & 285.4 \\
\hline & $\mathrm{C}-\mathrm{O}$ & 287.1 & 286.6 & 286.4 \\
\hline & $\mathrm{C}=\mathrm{O}$ & 288.6 & 288.2 & 288.1 \\
\hline & $\mathrm{C}-\mathrm{C}$ & 284.7 & 284.8 & 284.7 \\
\hline \multirow[t]{4}{*}{$0.15 \mathrm{mg} / \mathrm{mL}$} & C-H & - & 285.6 & 285.4 \\
\hline & $\mathrm{C}-\mathrm{O}$ & 286.8 & 286.6 & 286.4 \\
\hline & $\mathrm{C}=\mathrm{O}$ & 288.5 & 288.1 & 288.3 \\
\hline & $\mathrm{C}-\mathrm{C}$ & 284.7 & 284.8 & 284.7 \\
\hline \multirow[t]{3}{*}{$0.2 \mathrm{mg} / \mathrm{mL}$} & $\mathbf{C}-\mathbf{H}$ & - & 285.5 & 285.4 \\
\hline & $\mathrm{C}-\mathrm{O}$ & 286.7 & 286.5 & 286.2 \\
\hline & $\mathrm{C}=\mathrm{O}$ & 288.3 & 288.1 & 288.4 \\
\hline
\end{tabular}

Raman spectroscopy was used to explore any graphenic structural changes after the electrochemical reduction. The GO characteristic D vibrational band at $1355 \mathrm{~cm}^{-1}$ and $G$ band at $1601 \mathrm{~cm}^{-1}$ shifted for RGO, showing a D band at $1360 \mathrm{~cm}^{-1}$ and a $\mathrm{G}$ band at $1587 \mathrm{~cm}^{-1}$ (Figure 6). Besides this slight spectrum shift, the reduction of GO caused an increase in the D peak intensity $\left(\mathrm{I}_{\mathrm{D}}\right)$ and consequently the $\mathrm{I}_{\mathrm{D}} / \mathrm{I}_{\mathrm{G}}$ ratio increased from 0.8 to 1.15 . These results indicated an increased defect concentration in the structure of RGO relative to that of GO, that meant a decreased average size of $\mathrm{sp}^{2}$ domains upon GO reduction, in agreement with the previous reports which showed that new smaller sized graphitic domains were created upon GO reduction $[59,60]$.

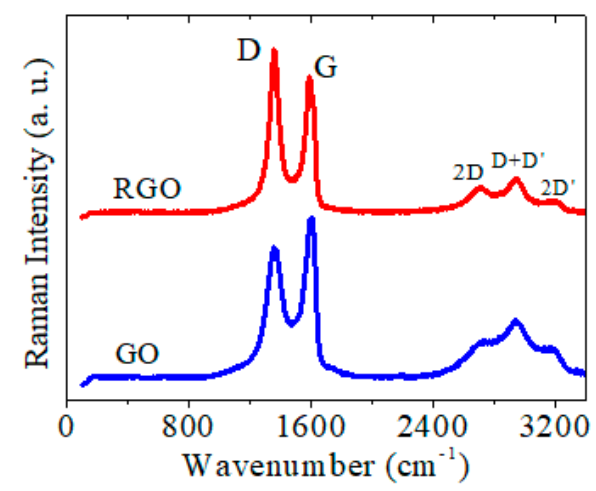

Figure 6. Raman spectra of GO and RGO (obtained by electrochemical reduction of GO films by five $\mathrm{CV}$ cycles from 0 to $-1.5 \mathrm{~V}, 0.05 \mathrm{~V} / \mathrm{s}$, in $0.5 \mathrm{M} \mathrm{KCl}$ ). 


\subsection{Electrochemical Characterization}

Different GO concentrations were applied to the commercially available SPCEs to determine that most suited for the fabrication of a DNA hybridization biosensor. Measurement reproducibility was critically improved when a preliminary two step electrochemical treatment was applied to as-received commercial SPCEs. The pretreatment consisted of five repetitive voltammetric cycles from +0.5 to $-1.5 \mathrm{~V}$ in $0.1 \mathrm{M} \mathrm{HCl}$, followed by two cycles from 0 to $+2 \mathrm{~V}$ in $0.1 \mathrm{M} \mathrm{PBS}, \mathrm{pH} 7$, at a scan rate of $0.05 \mathrm{~V} / \mathrm{s}$. Such activating treatment improved the electrochemical behavior of SPCEs such as peak-to-peak separation and electron transfer resistance (Rct) for the redox couple in the solution, and provided a hydrophilic carbon surface, facilitating the further deposition and adhesion of GO. Moreover, the addition of a small volume of PBS on the electrode could change the wetting properties of the surface to prevent spread of the GO beyond the outside border of the SPCE. This additional step proved to be essential for the GO coating reproducibility. Our studies showed that the $3 \mu \mathrm{L}$ solution volume sufficed to obtain a graphenic film of consistent thickness and reproducible electrochemical signal.

The electrochemical characterization in the presence of $1 \mathrm{mM}\left[\mathrm{Fe}(\mathrm{CN})_{6}\right]^{3-/ 4-}$ as a redox couple (Figure 7) showed no change in the current intensity (Figure 7a) or in the Rct values (Figure 7b) for the $0.05 \mathrm{mg} / \mathrm{mL}$ GO-SPCE-modified electrode compared to the bare electrode. At $0.1 \mathrm{mg} / \mathrm{mL}$ GO a decrease of redox peaks (Figure 7a) and a correlated increase of the Rct (Figure 7b) was observed. Furthermore, the results show similar CV signals (Figure 7a) and EIS spectra (Figure $7 \mathrm{~b}, \mathrm{~d}$ ) for $0.15 \mathrm{mg} / \mathrm{mL}$ and $0.2 \mathrm{mg} / \mathrm{mL} \mathrm{GO}$, respectively. Such behavior at the latter GO-SPCEs, consisting in lower $\left[\mathrm{Fe}(\mathrm{CN})_{6}\right]^{3-/ 4-}$ redox currents and increased Rct, could be envisioned as due to both the electrically insulating property of GO film and the repulsion of ferri/ferrocyanide ions with negatively charged functional groups of GO sheets.
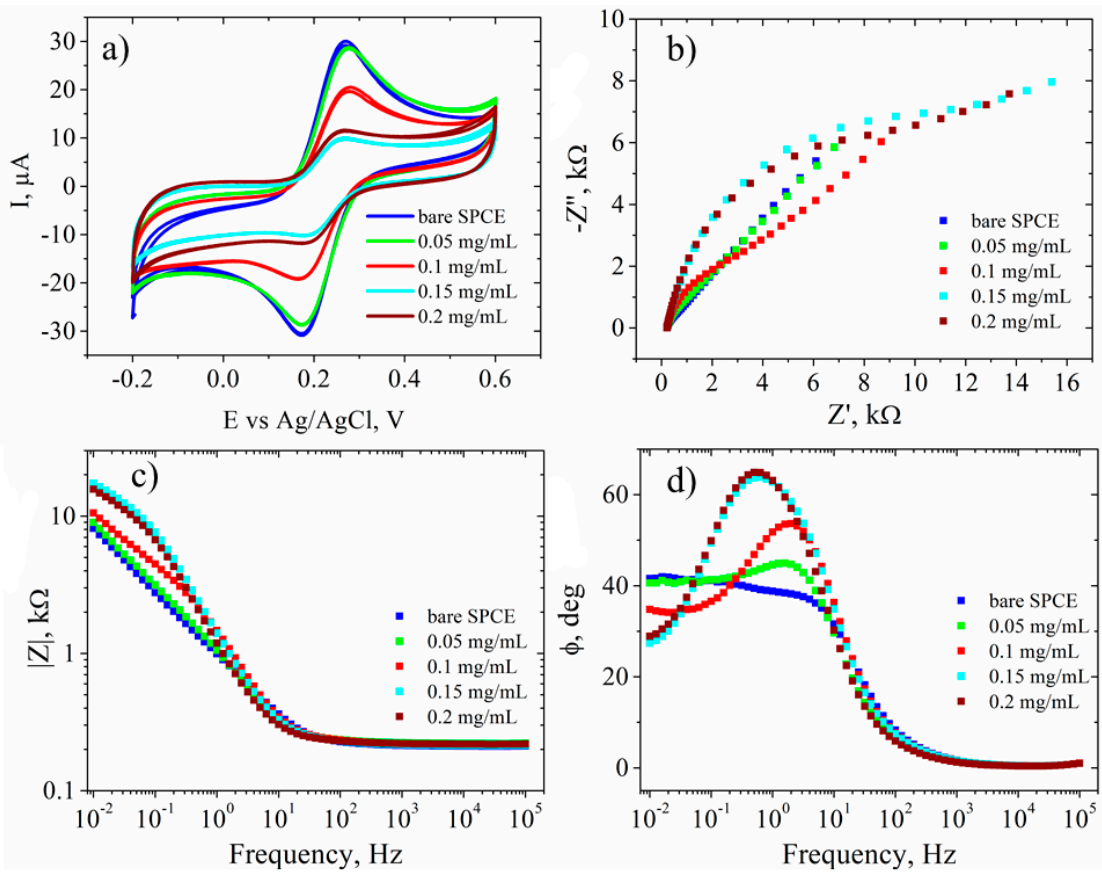

Figure 7. Electrochemical characterization: (a) CV; (b) EIS Nyquist plot; (c) EIS Bode plot-impedance modulus; (d) and phase shift. Characterizations were recorded in $1 \mathrm{mM}\left[\mathrm{Fe}(\mathrm{CN})_{6}\right]^{3-/ 4-}, 0.1 \mathrm{M} \mathrm{KCl}$, for bare SPCE (blue) and GO-SPCEs obtained using different concentrations of GO dispersions: $0.05 \mathrm{mg} / \mathrm{mL}$ (green), $0.1 \mathrm{mg} / \mathrm{mL}$ (red), $0.15 \mathrm{mg} / \mathrm{mL}$ (cyan), and $0.2 \mathrm{mg} / \mathrm{mL}$ (dark red).

In the next step of biosensor fabrication, GO films were electrochemically reduced by potential cycling between 0 and $-1.5 \mathrm{~V}(0.05 \mathrm{~V} / \mathrm{s})$ in $0.5 \mathrm{M} \mathrm{KCl}$ aqueous solutions and the corresponding $\mathrm{CVs}$ are illustrated in Figure 8. In the first potential cycle, a similar GO reduction peak was clearly distinguishable at approximately $-0.3 \mathrm{~V}$ for all four samples. Also, a second reduction peak was 
observed between $-1.0 \mathrm{~V}$ and $-1.1 \mathrm{~V}$ in all plots, less evident when using $0.05 \mathrm{mg} / \mathrm{mL}$ GO (Figure $8 \mathrm{a}$ ), but incrementally increased for higher GO dispersion concentrations. In the subsequent cycles the currents were diminished and the reduction peaks no longer observed, similar to other previously reported studies on the electrochemical reduction of GO [61]. A slight increase in the capacitive current with cycling was also observed due to an increased electrode active area from the gradually obtained RGO film. This behavior was more obvious when using $0.15 \mathrm{mg} / \mathrm{mL}$ and $0.2 \mathrm{mg} / \mathrm{mL}$ GO dispersions.
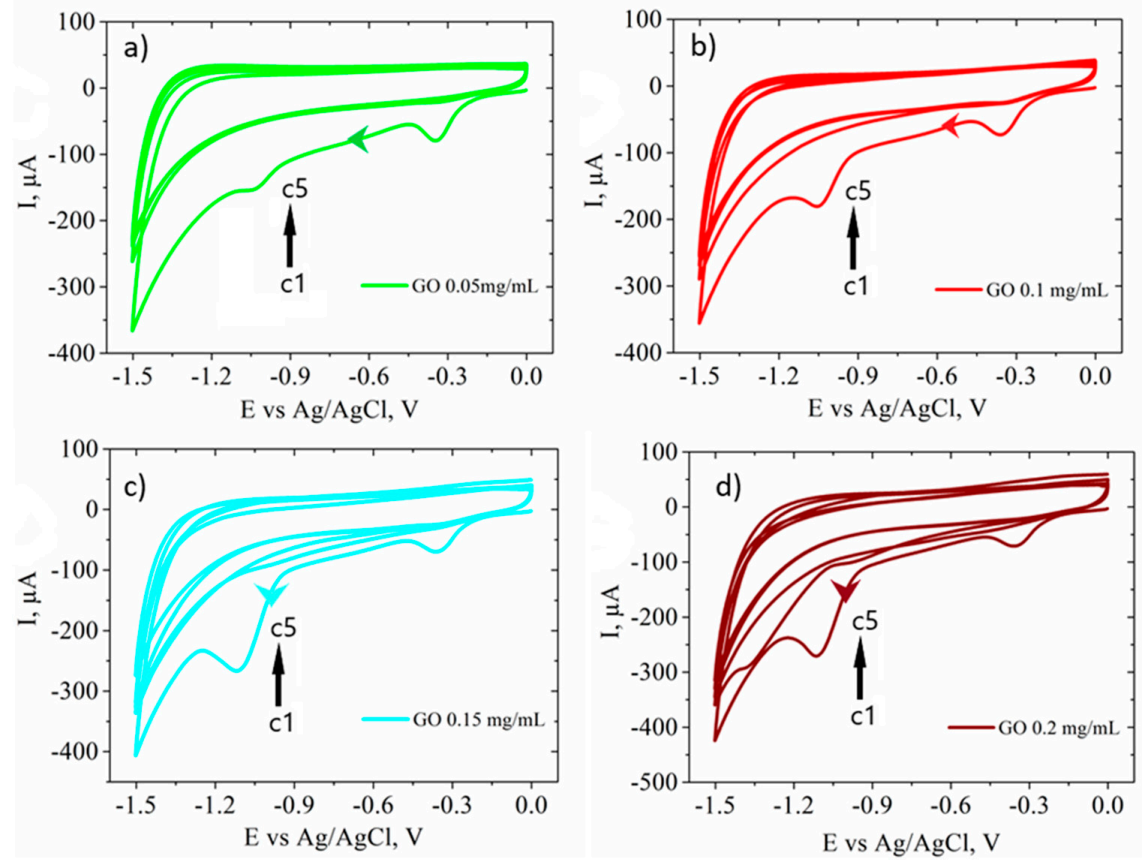

Figure 8. CVs (cycles (c) 1 to 5) showing the electrochemical reduction in $0.5 \mathrm{M} \mathrm{KCl}$ of GO-SPCEs obtained for different concentrations of GO dispersions: (a) $0.05 \mathrm{mg} / \mathrm{mL}$; (b) $0.1 \mathrm{mg} / \mathrm{mL}$; (c) $0.15 \mathrm{mg} / \mathrm{mL}$; and (d) $0.2 \mathrm{mg} / \mathrm{mL}$.

After the electrochemical reduction of GO to RGO sheets of higher conductivity and neutral structure, the kinetics of the redox probe at the GO-SPCE was significantly improved (accelerated electron transfer evidenced by a decreased Rct, lower phase shift and smaller impedance of the system). However, such characteristics were only clearly observed for $0.15 \mathrm{mg} / \mathrm{mL}$ and $0.2 \mathrm{mg} / \mathrm{mL}$ GO samples, while no substantial changes occurred for $0.05 \mathrm{mg} / \mathrm{mL}$ sample compared to bare SPCE (Figure 9).
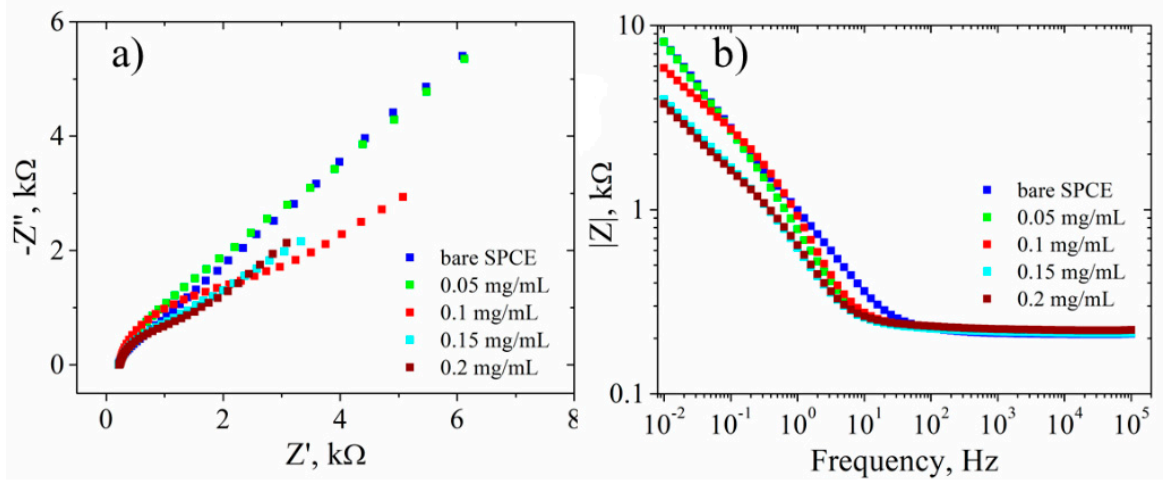

Figure 9. EIS characterization: (a) Nyquist plot; (b) EIS Bode plot-impedance modulus. Characterizations were recorded in $1 \mathrm{mM}\left[\mathrm{Fe}(\mathrm{CN})_{6}\right]^{3-/ 4-}, 0.1 \mathrm{M} \mathrm{KCl}$, for bare SPCE (blue) and RGO-SPCEs obtained using different concentrations of GO dispersions $0.05 \mathrm{mg} / \mathrm{mL}$ (green), $0.1 \mathrm{mg} / \mathrm{mL}$ (red), $0.15 \mathrm{mg} / \mathrm{mL}$ (cyan), and $0.2 \mathrm{mg} / \mathrm{mL}$ (dark red). 


\subsection{Electrode Response towards DNA Hybridization}

The same electrochemical tools were used to detect changes following the functionalization of the RGO electrodes with DNA probe and hybridization with the complementary DNA target. After immobilization of ssDNA probe on the surface of RGO-SPCEs, significant changes in the peak current's intensity and Rct of the ferri/ferrocyanide redox-active species from the test electrolyte were achieved for the samples that used higher GO concentrations, such as $0.15 \mathrm{mg} / \mathrm{mL}$ and $0.2 \mathrm{mg} / \mathrm{mL}$ rather than $0.05 \mathrm{mg} / \mathrm{mL}$ and $0.1 \mathrm{mg} / \mathrm{mL}$ (Figure 10). This behavior could be explained by the fact that immobilized ssDNA with a negatively charged phosphate backbone imparted an electrostatic repulsive force to $\left[\mathrm{Fe}(\mathrm{CN})_{6}\right]^{3-/ 4-}$. Moreover, an increased thickness of the RGO film (obtained using higher initial GO concentrations) enhanced the accumulation of immobilized ssDNA probe, that could eventually lead to an improved sensitivity of the biosensor. An enhanced signal change, and thus a higher sensitivity, were achieved for the samples that used higher GO concentrations. The included SEM images indicated an increased thickness of GO layers with the increase of the dispersion concentration. Such behavior could be explained by the fact that an enhanced signal change indicated DNA hybridization, while minimal signal change indicated less binding. This suggested that more complementary ssDNA probe was adsorbed on $0.15 \mathrm{mg} / \mathrm{mL}$ and $0.2 \mathrm{mg} / \mathrm{mL}$ GO-based electrodes, because they exhibited significant response while use of other GO concentrations showed low or no change in signal.
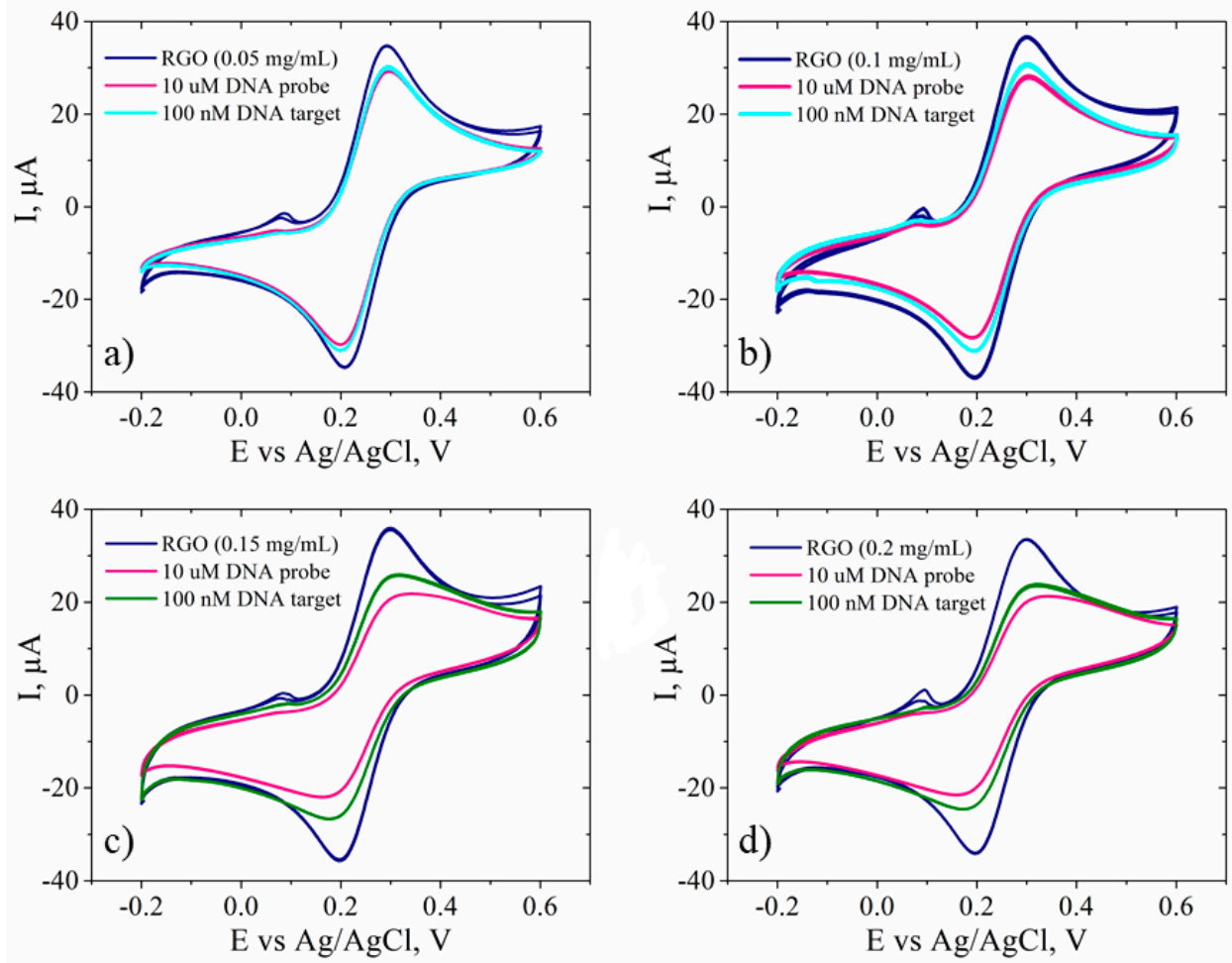

Figure 10. $\mathrm{CV}$ measurements recorded in $1 \mathrm{mM}\left[\mathrm{Fe}(\mathrm{CN})_{6}\right]^{3-/ 4-}, 0.1 \mathrm{M} \mathrm{KCl}$, for RGO-SPCEs based on (a) $0.05 \mathrm{mg} / \mathrm{mL}$; (b) $0.1 \mathrm{mg} / \mathrm{mL}$; (c) $0.15 \mathrm{mg} / \mathrm{mL}$; and (d) $0.2 \mathrm{mg} / \mathrm{mL}$ GO dispersions, after adsorption of ssDNA probe $(10 \mu \mathrm{M})$ and hybridization with $100 \mathrm{nM}$ DNA target.

The hybridization reaction was carried out by incubating ssDNA/RGO-SPCE functionalized electrodes in $30 \mu \mathrm{L}$ DNA target $(100 \mathrm{nM})$ at $58^{\circ} \mathrm{C}$ for one hour. The subsequent characterization of the hybridized electrodes by $\mathrm{CV}$ in the presence of the redox probes showed, with the exception of only the $0.05 \mathrm{mg} / \mathrm{mL}$ sample, an increase of the peak currents and a reduction in peak-to-peak separation (Figure 10). This effect stemming from a more favorable kinetics for $\left[\mathrm{Fe}(\mathrm{CN})_{6}\right]^{3-/ 4-}$ is more clearly evidenced by the chart in Figure 11, where we provide a complete comparison of the redox species response in $\mathrm{CV}$ after each modification stage of the electrodes. Since the ssDNA was noncovalently 
adsorbed to the RGO-SPCEs, hybridization with the complementary oligonucleotide sequence readily induced desorption of the dsDNA target-conjugated probes from RGO surfaces [37,40,62], favoring the redox reaction of $\left[\mathrm{Fe}(\mathrm{CN})_{6}\right]^{3-/ 4-}$. Hence, the Rct values should decrease upon dsDNA formation, and such a sensitive impedimetric signal was achieved when using $0.15 \mathrm{mg} / \mathrm{mL}$ and $0.2 \mathrm{mg} / \mathrm{mL} \mathrm{GO}$ samples (Figures 12 and 13).
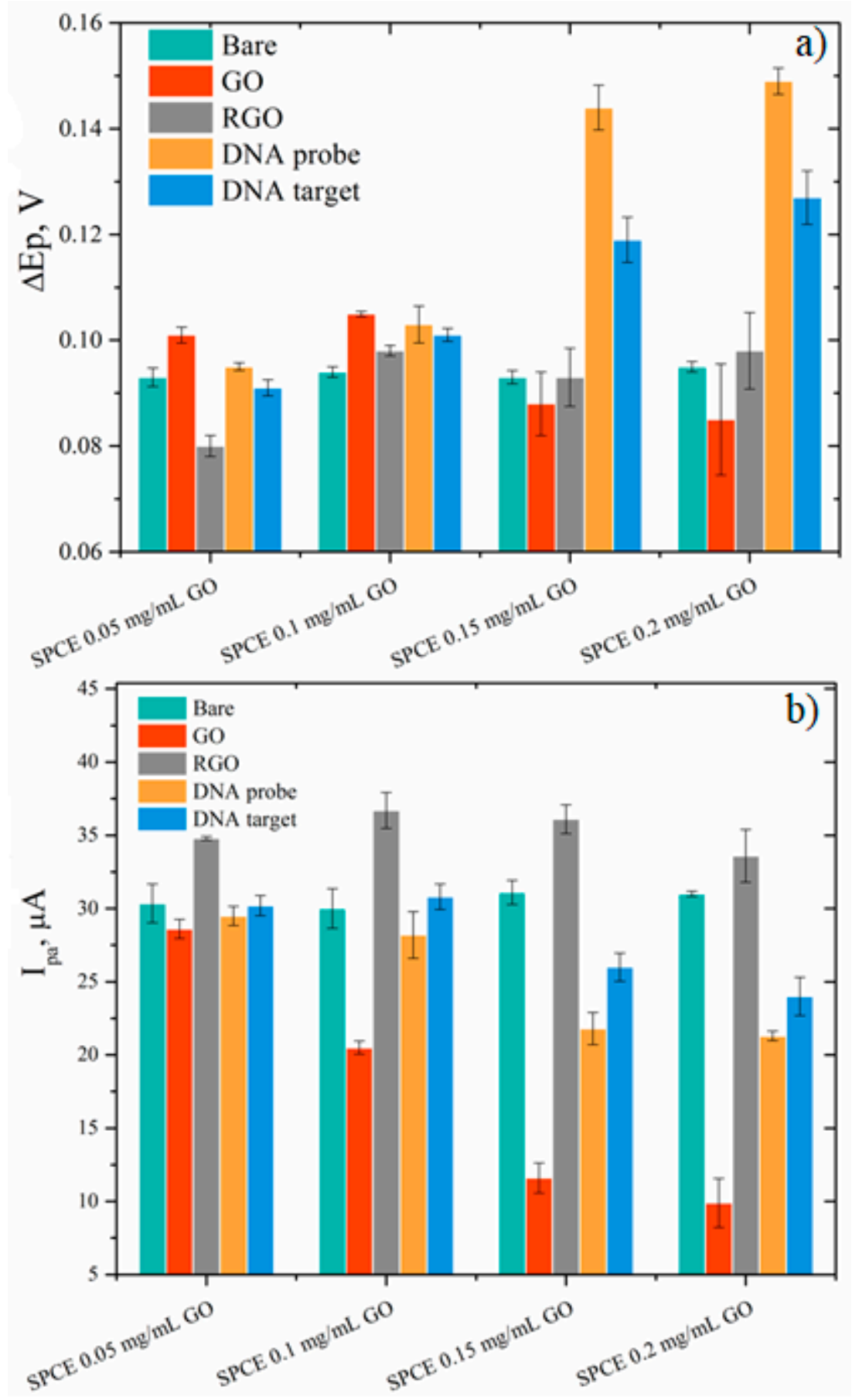

Figure 11. (a) Peak separation values $\left(\Delta \mathrm{E}_{\mathrm{p}}\right)(\mathbf{b})$ and anodic peak currents $\left(\mathrm{I}_{\mathrm{pa}}\right)$ resulting from $C V$ measurements recorded in $1 \mathrm{mM}\left[\mathrm{Fe}(\mathrm{CN})_{6}\right]^{3-/ 4-}, 0.1 \mathrm{M} \mathrm{KCl}$, after every modification stage of SPCEs electrodes: drop-casting of GO dispersions of different concentrations (GO), electrochemical reduction of GO (RGO), adsorption of ssDNA probe $(10 \mu \mathrm{M})$ on RGO-SPCEs (DNA probe) and hybridization with $100 \mathrm{nM}$ target DNA (DNA target). Error bars represent standard deviation with $n=3$. 

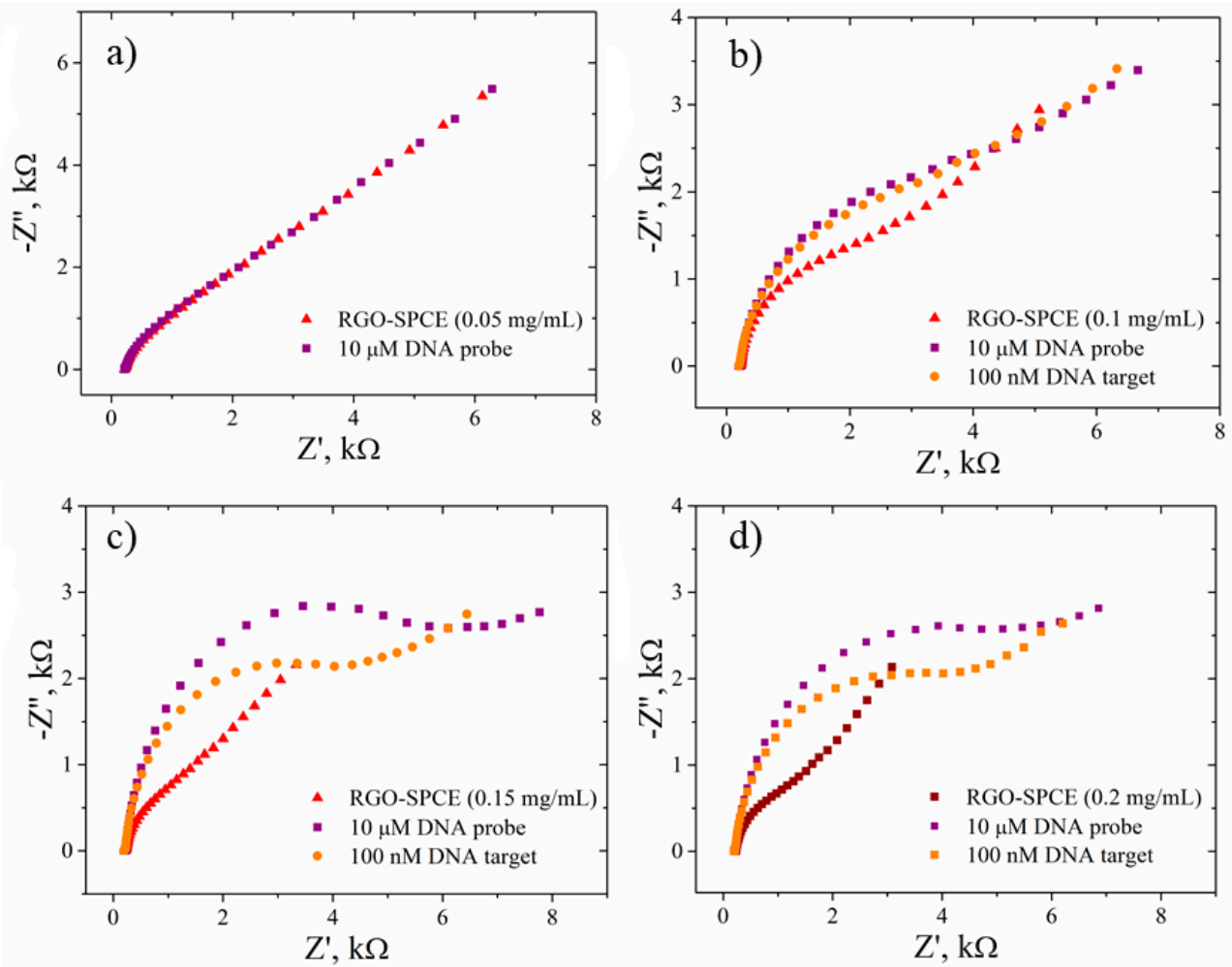

Figure 12. EIS measurements (Nyquist spectra) recorded in $1 \mathrm{mM}\left[\mathrm{Fe}(\mathrm{CN})_{6}\right]^{3-/ 4-}, 0.1 \mathrm{M} \mathrm{KCl}$, for RGO-SPCEs based on (a) $0.05 \mathrm{mg} / \mathrm{mL}$; (b) $0.1 \mathrm{mg} / \mathrm{mL}$; (c) $0.15 \mathrm{mg} / \mathrm{mL}$; and (d) $0.2 \mathrm{mg} / \mathrm{mL}$ GO dispersions, after adsorption of ssDNA probe $(10 \mu \mathrm{M})$ and hybridization with $100 \mathrm{nM}$ DNA target.

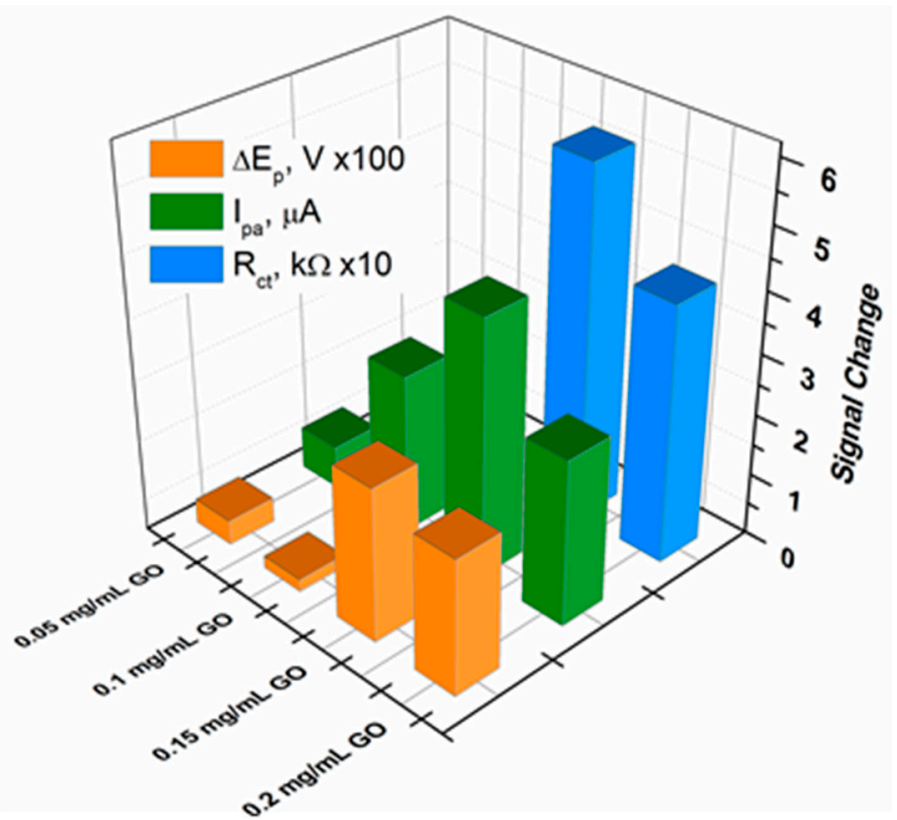

Figure 13. Signal change in peak current intensities (Ipa), peak-to-peak separation potentials $(\Delta \mathrm{Ep})$ and charge transfer resistance values obtained from EIS measurements (Rct, quality of fitting $\chi^{2}=0.051$ \pm 0.022 ) after hybridization with $100 \mathrm{nM}$ DNA target in respect with the measured values after ssDNA probe adsorption.

Once again, it was obvious that for the samples prepared with low concentrations of GO dispersion, the changes in the electrochemical signal upon DNA hybridization were not as substantial as those observed for $0.15 \mathrm{mg} / \mathrm{mL}$ and $0.2 \mathrm{mg} / \mathrm{mL}$ GO. Moreover, at a very careful analysis of the results 
obtained for these most favorable GO concentrations, one can observe a better sensitivity in DNA target detection for the electrode prepared with $0.15 \mathrm{mg} / \mathrm{mL} \mathrm{GO}$ (Figure 13). This outcome correlated very well with the XPS result that suggested a maximal ssDNA probe immobilization for the same sample.

\section{Conclusions}

This work presents a study on the influence induced by the concentration of GO dispersion as a modifier on commercially available SPCEs for developing RGO-SPCEs for electrochemical detection of DNA hybridization.

A new and simple protocol consisting of two-step electrochemical treatment of the SPCEs was also proposed in order to achieve a reproducible deposition of GO on SPCEs. The pretreatment consisted of five repetitive voltammetric cycles from +0.5 to $-1.5 \mathrm{~V}$ in $0.1 \mathrm{M} \mathrm{HCl}$, followed by two cycles from 0 to $+2 \mathrm{~V}$ in $0.1 \mathrm{M}$ PBS, pH 7, at a scan rate of $0.05 \mathrm{~V} / \mathrm{s}$. This process substantially improved the electrochemical properties of the electrodes and facilitated the further deposition and adhesion of GO. Furthermore, an additional step of casting a small volume of PBS on the electrode to control the wetting properties of the surface proved to be essential for the coating reproducibility.

This novel procedure for SPCE pretreatment would be broadly applicable to the fabrication of many types of disposable biosensors. The reproducibility of the deposited film could allow the scaling of the method to fabricate electrochemical sensing platforms with larger surface areas than those produced by conventional drop-casting, but further studies demonstrating such feasibility are needed.

Signal amplification is an important parameter for DNA hybridization biosensors, and we have demonstrated that the sensitivity of the RGO-SPCEs as DNA hybridization detection platform could be tuned by varying the concentration of aqueously dispersed GO used for SPCE modification. Best results in terms of sensitivity were obtained using $0.15 \mathrm{mg} / \mathrm{mL} \mathrm{GO}$.

Our work represents a proof-of-concept approach for fabricating reproducible screen-printed RGO electrodes that are paving the way for large-scale graphene-based sensing platforms in the future.

Author Contributions: For research articles with several authors, a short paragraph specifying their individual contributions must be provided. Conceptualization, M.I. and E.A.C.; Methodology, E.A.C., M.I. and L.P.; Software, E.A.C.; Validation, E.A.C., L.P. and M.I.; Formal Analysis, E.A.C., L.P.; Investigation, E.A.C., C.-M.D. and E.V.; Resources, M.I., J.S.B.; Data Curation, E.A.C. and L.P.; Writing-original draft preparation, E.A.C.; Writing-review and editing, L.P. and J.S.B.; Supervision, M.I.; Project Administration, M.I. and J.S.B.; Funding acquisition, M.I. and J.S.B.

Funding: This work was supported by a grant of the Ministry of Research and Innovation, Operational Program Competitiveness Axis 1-Section E, Program co-financed from European Regional Development Fund under the project number 154/25.11.2016, P_37_221/2015, “A novel graphene biosensor testing osteogenic potency; capturing best stem cell performance for regenerative medicine" (GRABTOP).

Conflicts of Interest: The authors declare no conflict of interest.

\section{References}

1. Balaji, A.; Yang, S.; Wang, J.; Zhang, J. Graphene Oxide-Based Nanostructured DNA Sensor. Biosensors 2019, 9, 74. [CrossRef] [PubMed]

2. $\quad$ Liang, S.-S.; Qi, L.; Zhang, R.-L.; Jin, M.; Zhang, Z.-Q. Zhang. Ratiometric fluorescence biosensor based on CdTe quantum and carbon dots for double strand DNA detection. Sens. Actuators B Chem. 2017, 244, 585-590. [CrossRef]

3. Diao, W.; Tang, M.; Ding, S.; Li, X.; Cheng, W.; Mo, F.; Yan, X.; Ma, H.; Yan, Y. Highly sensitive surface plasmon resonance biosensor for the detection of HIV-related DNA based on dynamic and structural DNA nanodevices. Biosens. Bioelectron. 2018, 100, 228-234. [CrossRef] [PubMed]

4. Luo, M.; Chen, X.; Zhou, G.; Xiang, X.; Chen, L.; Ji, X.; He, Z. Chemiluminescence biosensors for DNA detection using graphene oxide and a horseradish peroxidase-mimicking DNAzyme. Chem. Commun. 2012, 48, 1126-1128. [CrossRef] [PubMed] 
5. Li, R.; Zou, L.; Luo, Y.; Zhang, M.; Ling, L. Ultrasensitive colorimetric detection of circulating tumor DNA using hybridization chain reaction and the pivot of triplex DNA. Sci. Rep. 2017, 7, 44212. [CrossRef] [PubMed]

6. Rijal, K.; Mutharasan, R. A method for DNA-based detection of E. coli O157:H7 in a proteinous background using piezoelectric-excited cantilever sensors. Analyst 2013, 138, 2943-2950. [CrossRef]

7. Ye, Y.; Xie, J.; Ye, Y.; Cao, X.; Zheng, H.; Xu, X.; Zhang, Q. A label-free electrochemical DNA biosensor based on thionine functionalized reduced graphene oxide. Carbon 2018, 129, 730-737. [CrossRef]

8. Huang, J.; Zhang, S.; Mo, F.; Su, S.; Chen, X.; Li, Y.; Fang, L.; Huang, H.; Deng, J.; Liu, H.; et al. An electrochemical DNA biosensor analytic technique for identifying DNA methylation specific sites and quantify DNA methylation level. Biosens. Bioelectron. 2019, 127, 155-160. [CrossRef]

9. Manzano, M.; Viezzi, S.; Mazerat, S.; Marks, R.S.; Vidic, J. Rapid and label-free electrochemical DNA biosensor for detecting hepatitis A virus. Biosens. Bioelectron. 2018, 100, 89-95. [CrossRef]

10. Zhang, X.; Jiao, K.; Liu, S.; Hu, Y. Readily reusable electrochemical DNA hybridization biosensor based on the interaction of DNA with single-walled carbon nanotubes. Anal. Chem. 2009, 81, 6006-6012. [CrossRef]

11. Ricci, F.; Bonham, A.J.; Mason, A.C.; Reich, N.O.; Plaxco, K.W. Reagentless, electrochemical approach for the specific detection of double-and single-stranded DNA binding proteins. Anal. Chem. 2009, 81, 1608-1614. [CrossRef] [PubMed]

12. Zhang, W.; Yang, T.; Zhuang, X.; Guo, Z.; Jiao, K. An ionic liquid supported CeO2 nanoshuttles-carbon nanotubes composite as a platform for impedance DNA hybridization sensing. Biosens. Bioelectron. 2009, 24, 2417-2422. [CrossRef] [PubMed]

13. Park, J.-Y.; Park, S.-M. DNA hybridization sensors based on electrochemical impedance spectroscopy as a detection tool. Sensors 2009, 9, 9513-9532. [CrossRef] [PubMed]

14. Asal, M.; Özen, Ö.; Şahinler, M.; Polatoğlu, İ. Recent developments in enzyme, DNA and immuno-based biosensors. Sensors 2018, 18, 1924. [CrossRef] [PubMed]

15. Yáñez-Sedeño, P.; Campuzano, S.; Pingarrón, J. Carbon nanostructures for tagging in electrochemical biosensing: A Review. C 2017,3, 3. [CrossRef]

16. Grieshaber, D.; MacKenzie, R.; Vörös, J.; Reimhult, E. Electrochemical Biosensors-Sensor Principles and Architectures. Sensors 2008, 8, 1400-1458. [CrossRef] [PubMed]

17. Mills, D.M.; Martin, C.P.; Armas, S.M.; Calvo-Marzal, P.; Kolpashchikov, D.M.; Chumbimuni-Torres, K.Y. A universal and label-free impedimetric biosensing platform for discrimination of single nucleotide substitutions in long nucleic acid strands. Biosens. Bioelectron. 2018, 109, 35-42. [CrossRef] [PubMed]

18. Lasia, A. Definition of Impedance and Impedance of Electrical Circuits. In Electrochemical Impedance Spectroscopy and its Applications; Springer: New York, NY, USA, 2014; pp. 7-66.

19. Grossi, M.; Riccò, B. Electrical impedance spectroscopy (EIS) for biological analysis and food characterization: A review. J. Sens. Sens. Syst. 2017, 6, 303-325. [CrossRef]

20. Tiginyanu, I.; Topala, P.; Ursaki, V. Nanostructures and Thin Films for Multifunctional Applications: Technology, Properties and Devices; Springer International Publishing: Berlin/Heidelberg, Germany, 2016.

21. Han, L.; Liu, P.; Petrenko, V.A.; Liu, A. A Label-Free Electrochemical Impedance Cytosensor Based on Specific Peptide-Fused Phage Selected from Landscape Phage Library. Sci. Rep. 2016, 6, 22199. [CrossRef]

22. Wu, X.; Mu, F.; Wang, Y.; Zhao, H. Graphene and Graphene-Based Nanomaterials for DNA Detection: A Review. Molecules 2018, 23, 2050. [CrossRef]

23. Davies, T.J.; Hyde, M.E.; Compton, R.G. Nanotrench Arrays Reveal Insight into Graphite Electrochemistry. Angew. Chem. Int. Ed. 2005, 44, 5121-5126. [CrossRef] [PubMed]

24. Johnson, D.W.; Dobson, B.; Coleman, K.S. A manufacturing perspective on graphene dispersions. Curr. Opin. Colloid Interface Sci. 2015, 20, 367-382. [CrossRef]

25. Konkena, B.; Vasudevan, S. Understanding Aqueous Dispersibility of Graphene Oxide and Reduced Graphene Oxide through pKa Measurements. J. Phys. Chem. Lett. 2012, 3, 867-872. [CrossRef] [PubMed]

26. Gao, W.; Alemany, L.B.; Ci, L.; Ajayan, P.M. New insights into the structure and reduction of graphite oxide. Nat. Chem. 2009, 1, 403. [CrossRef] [PubMed]

27. Raicopol, M.; Vlsceanu, I.; Lupulescu, I.; Brezoiu, A.M.; Pilan, L. Amperometric glucose biosensors based on functionalized electrochemically reduced graphene oxide. U.P.B. Sci. Bull. Ser. B 2016, 78, 131-142. 
28. Baez, D.F.; Pardo, H.; Laborda, I.; Marco, J.F.; Yanez, C.; Bollo, S. Reduced Graphene Oxides: Influence of the Reduction Method on the Electrocatalytic Effect towards Nucleic Acid Oxidation. Nanomaterials 2017, 7, 168. [CrossRef] [PubMed]

29. Liu, J. Adsorption of DNA onto gold nanoparticles and graphene oxide: Surface science and applications. Phys. Chem. Chem. Phys. 2012, 14, 10485-10496. [CrossRef]

30. Becheru, D.F.; Vlasceanu, G.M.; Banciu, A.; Vasile, E.; Ionita, M.; Burns, J.S. Optical Graphene-Based Biosensor for Nucleic Acid Detection; Influence of Graphene Functionalization and Ionic Strength. Int. J. Mol. Sci. 2018, 19, 3230. [CrossRef]

31. Park, J.S.; Goo, N.I.; Kim, D.E. Mechanism of DNA adsorption and desorption on graphene oxide. Langmuir 2014, 30, 12587-12595. [CrossRef]

32. Liu, B.; Salgado, S.; Maheshwari, V.; Liu, J. DNA adsorbed on graphene and graphene oxide: Fundamental interactions, desorption and applications. Curr. Opin. Colloid Interface Sci. 2016, 26, 41-49. [CrossRef]

33. Zeng, S.; Chen, L.; Wang, Y.; Chen, J. Exploration on the mechanism of DNA adsorption on graphene and graphene oxide via molecular simulations. J. Phys. D Appl. Phys. 2015, 48, 275402. [CrossRef]

34. Zhang, X.; Wang, Y.; Luo, G.; Xing, M. Two-Dimensional Graphene Family Material: Assembly, Biocompatibility and Sensors Applications. Sensors 2019, 19, 2966. [CrossRef] [PubMed]

35. Pumera, M. Graphene in biosensing. Mater. Today 2011, 14, 308-315. [CrossRef]

36. Liu, M.; Song, J.; Shuang, S.; Dong, C.; Brennan, J.D.; Li, Y. A graphene-based biosensing platform based on the release of DNA probes and rolling circle amplification. ACS Nano 2014, 8, 5564-5573. [CrossRef] [PubMed]

37. Giovanni, M.; Bonanni, A.; Pumera, M. Detection of DNA hybridization on chemically modified graphene platforms. Analyst 2012, 137, 580-583. [CrossRef]

38. Benvidi, A.; Rajabzadeh, N.; Zahedi, H.M.; Mazloum-Ardakani, M.; Heidari, M.M.; Hosseinzadeh, L. Simple and label-free detection of DNA hybridization on a modified graphene nanosheets electrode. Talanta 2015, 137, 80-86. [CrossRef] [PubMed]

39. Li, B.; Pan, G.; Avent, N.D.; Lowry, R.B.; Madgett, T.E.; Waines, P.L. Graphene electrode modified with electrochemically reduced graphene oxide for label-free DNA detection. Biosens. Bioelectron. 2015, 72, 313-319. [CrossRef] [PubMed]

40. Bonanni, A.; Pumera, M. Graphene Platform for Hairpin-DNA-Based Impedimetric Genosensing. ACS Nano 2011, 5, 2356-2361. [CrossRef]

41. Smith, J.P.; Metters, J.P.; Kampouris, D.K.; Lledo-Fernandez, C.; Sutcliffe, O.B.; Banks, C.E. Forensic electrochemistry: The electroanalytical sensing of Rohypnol@(flunitrazepam) using screen-printed graphite electrodes without recourse for electrode or sample pre-treatment. Analyst 2013, 138, 6185-6191. [CrossRef]

42. Metters, J.; Kadara, R.O.; Banks, C.E. New directions in screen printed electroanalytical sensors: An overview of recent developments. Analyst 2011, 136, 1067-1076. [CrossRef]

43. Wang, J.; Xu, Z.; Zhang, M.; Liu, J.; Zou, H.; Wang, L. Improvement of electrochemical performance of screen-printed carbon electrodes by UV/ozone modification. Talanta 2019, 192, 40-45. [CrossRef] [PubMed]

44. Muhammad, A.; Hajian, R.; Yusof, N.A.; Shams, N.; Abdullah, J.; Woi, P.M.; Garmestani, H. A screen printed carbon electrode modified with carbon nanotubes and gold nanoparticles as a sensitive electrochemical sensor for determination of thiamphenicol residue in milk. RSC Adv. 2018, 8, 2714-2722. [CrossRef]

45. Ibáñez-Redín, G.; Wilson, D.; Gonçalves, D.; Oliveira Jr, O. Low-cost screen-printed electrodes based on electrochemically reduced graphene oxide-carbon black nanocomposites for dopamine, epinephrine and paracetamol detection. J. Colloid Interface Sci. 2018, 515, 101-108. [CrossRef] [PubMed]

46. González-Sánchez, M.I.; Gómez-Monedero, B.; Agrisuelas, J.; Iniesta, J.; Valero, E. Highly activated screen-printed carbon electrodes by electrochemical treatment with hydrogen peroxide. Electrochem. Commun. 2018, 91, 36-40. [CrossRef]

47. Li, S.; Zhang, Q.; Lu, Y.; Ji, D.; Zhang, D.; Wu, J.; Chen, X.; Liu, Q. One step electrochemical deposition and reduction of graphene oxide on screen printed electrodes for impedance detection of glucose. Sens. Actuators B Chem. 2017, 244, 290-298. [CrossRef]

48. Ndiaye, A.; Delile, S.; Brunet, J.; Varenne, C.; Pauly, A. Electrochemical sensors based on screen-printed electrodes: The use of phthalocyanine derivatives for application in VFA detection. Biosensors 2016, 6, 46. [CrossRef] [PubMed] 
49. Su, W.-Y.; Wang, S.-M.; Cheng, S.-H. Electrochemically pretreated screen-printed carbon electrodes for the simultaneous determination of aminophenol isomers. J. Electroanal. Chem. 2011, 651, 166-172. [CrossRef]

50. Díaz-González, M.; de la Escosura-Muñiz, A.; González-García, M.B.; Costa-García, A. DNA hybridization biosensors using polylysine modified SPCEs. Biosens. Bioelectron. 2008, 23, 1340-1346. [CrossRef]

51. Chen, Y.; Gong, X.L.; Gai, J.G. Progress and Challenges in Transfer of Large-Area Graphene Films. Adv. Sci. 2016, 3, 1500343. [CrossRef]

52. Zhong, Y.L.; Tian, Z.; Simon, G.P.; Li, D. Scalable production of graphene via wet chemistry: Progress and challenges. Mater. Today 2015, 18, 73-78. [CrossRef]

53. Randviir, E.P.; Brownson, D.A.; Metters, J.P.; Kadara, R.O.; Banks, C.E. The fabrication, characterisation and electrochemical investigation of screen-printed graphene electrodes. Phys. Chem. Chem. Phys. 2014, 16, 4598-4611. [CrossRef] [PubMed]

54. Valentini, F.; Romanazzo, D.; Carbone, M.; Palleschi, G. Modified Screen-Printed Electrodes Based on Oxidized Graphene Nanoribbons for the Selective Electrochemical Detection of Several Molecules. Electroanalysis 2012, 24, 872-881. [CrossRef]

55. Eissa, S.; Tlili, C.; L'Hocine, L.; Zourob, M. Electrochemical immunosensor for the milk allergen beta-lactoglobulin based on electrografting of organic film on graphene modified screen-printed carbon electrodes. Biosens. Bioelectron. 2012, 38, 308-313. [CrossRef] [PubMed]

56. Mensing, J.P.; Kerdcharoen, T.; Sriprachuabwong, C.; Wisitsoraat, A.; Phokharatkul, D.; Lomas, T.; Tuantranont, A. Facile preparation of graphene-metal phthalocyanine hybrid material by electrolytic exfoliation. J. Mater. Chem. 2012, 22, 17094-17099. [CrossRef]

57. Karuwan, C.; Sriprachuabwong, C.; Wisitsorrat, A.; Ditsayut, P.; Sritongkham, P.; Tuantranont, A. Inkjet-printed graphene-poly(3,4-ethylenedioxythiophene):Poly(styrene-sulfonate) modified on screen printed carbon electrode for electrochemical sensing of salbutamol. Sens. Actuators B Chem. 2012, 161, 549-555. [CrossRef]

58. Sriprachuabwong, C.; Karuwan, C.; Wisitsorrat, A.; Phokharatkul, D.; Lomas, T.; Sritongkham, P.; Tuantranont, A. Inkjet-printed graphene-PEDOT:PSS modified screen printed carbon electrode for biochemical sensing. J. Mater. Chem. 2012, 22, 5478-5485. [CrossRef]

59. Stankovich, S.; Dikin, D.A.; Piner, R.D.; Kohlhaas, K.A.; Kleinhammes, A.; Jia, Y.; Wu, Y.; Nguyen, S.T.; Ruoff, R.S. Synthesis of graphene-based nanosheets via chemical reduction of exfoliated graphite oxide. Carbon 2007, 45, 1558-1565. [CrossRef]

60. Ramesha, G.K. and S. Sampath, Electrochemical Reduction of Oriented Graphene Oxide Films: An in Situ Raman Spectroelectrochemical Study. J. Phys. Chem. C 2009, 113, 7985-7989. [CrossRef]

61. Haque, A.-M.J.; Park, H.; Sung, D.; Jon, S.; Choi, S.-Y.; Kim, K. An Electrochemically Reduced Graphene Oxide-Based Electrochemical Immunosensing Platform for Ultrasensitive Antigen Detection. Anal. Chem. 2012, 84, 1871-1878. [CrossRef]

62. Wu, M.; Kempaiah, R.; Huang, P.-J.J.; Maheshwari, V.; Liu, J. Adsorption and Desorption of DNA on Graphene Oxide Studied by Fluorescently Labeled Oligonucleotides. Langmuir 2011, 27, 2731-2738. [CrossRef] 